\title{
WORK PRECARIOUSNESS, JOB INSECURITY AND PERCEIVED PSYCHIATRIC DISTRESS IN A SAMPLE OF EGYPTIAN EMPLOYEES
}

\author{
By \\ Zalat MM and Sheta SS \\ Department of Community, Occupational and Environmental Medicine, Zagazig \\ University, Zagazig, Egypt. \\ Corresponding author: Zalat MM: Mzalat@taibahu.edu.sa
}

\begin{abstract}
Introduction: The term precarious work is being increasingly used worldwide. Workers are precarious if they are in involuntary part-time work, in seasonal or casual work or in temporary jobs without a legal work contract or formal appointment. Precarious work becomes a global challenge and constituting a serious problem threatens the well-being of workers and their families. Aim of work: To verify the existence and prevalence of job insecurity and precarious employment among a sample of Egyptian workers and to clarify the role of perceived job insecurity and work precariousness on the worker's mental health. Materials and methods: A comparative cross-sectional study was conducted on 130 subjects of private and public sector workers in Zagazig city, Egypt. Employment Precariousness Scale was used for measuring the employment precariousness and General Health Questionnaire was used for estimating the minor psychiatric morbidity. Results: The majority of private sector workers showed a statistically significant high/very high level of precariousness and job insecurity $(87.7 \%$, and $69.2 \%$ respectively) compared to the public sector. Only $10.8 \%$ of public sector showed poor mental health compared to $30.8 \%$ for the private sector with a statistically significant difference. Unsatisfied income, having another or second job, perceived work precariousness and job insecurity demonstrated significant prediction for psychiatric distress. Conclusion and recommendations: The private sector workers suffered a higher prevalence of work precariousness, job insecurity, and poor mental health in comparison to public sector workers. Precarious work should be regarded as an important social determinant of mental health problems which necessitate urgent interventions with policy tools in order to improve health, increase firms' productivity, and so wider economic impact.
\end{abstract}

Keywords: Work, Precarious, Job insecurity, Psychiatric distress, Private and public sectors. 


\section{Introduction}

Over recent years, the term precarious employment is being increasingly used worldwide. The transformations in organizations and the labor market have produced an increase in precarious work, employee job insecurity and become representing a serious problem threatens the well-being of workers and their families, however; it is seldom studied (Ruiz et al., 2017). According to the International Labor Organization (ILO), precarious work is a work performed in the formal and informal economy and is characterized by variable levels and degrees of objective (legal status) and subjective (feeling) characteristics of uncertainty and insecurity (ILO, 2012). Changing global employment trends, marked by increased calls for a 'flexible workforce' have led to an increase in the number of temporary workers, including those on part-time contracts, pseudo-selfemployment, subcontractors, and on-call contracts (Puig-Barrachina et al., 2014). Workers are precarious if they are in involuntary part-time work, in seasonal or casual work or in temporary jobs without a legal work contract (Rashad and Sharaf, 2018). Precarious workers have limited access to social benefits and health insurance. They receive low pay and encounter dangerous working conditions, and a higher risk of work injuries (Benach et al., 2014). The extent of the precariousness of employment in any given country is contingent on the social, economic, and political processes driving the labor market and welfare state policies (Muntaner et al., 2010). In Egyptian labor market, the figure of parttime, temporary, working on contract, holding multiple jobs or own account self-employed have been increased in the recent years, especially the Egyptian labor laws allow employers to close or downsize the workforce for economic reasons which is fluctuating since the economic crisis accompanying the January 25 th, 2011 revolution (Egypt's government services portal, 2017). Approximately two-thirds of workers in Egypt were employed informally with an increasing share of precarious work from $8 \%$ in 2006 to $17 \%$ in 2012 (Aita, 2017). This greater precariousness of employment constitutes a global challenge that has a wide range of potential consequences to health.

\section{Aim of work}

To verify the existence and prevalence of job insecurity and precarious employment among a sample of Egyptian workers (private 
and public sectors) and to clarify the role of perceived job insecurity and work precariousness on the worker's mental health.

\section{Materials and methods}

Study design: It is a comparative cross-sectional study.

Place and duration of the study: This study was conducted to a sample of private and public firms in Zagazig city, Sharkia Governorate, Egypt from January 1 st to February 28 th, 2018.

\section{Study sample:}

1- Private sector: According to the official data from Zagazig City Council, the total number of private firms with tax-paying legal entity: pharmaceutical stores, telecommunications main offices and non-governmental tourism companies. In Zagazig city, at the time of the study; there were 19 private firms; 5 drug stores, 6 tourism companies, and 8 main telecommunication offices with total number of 127 employees.

2- Public sector (comparative group): A comparative group of administrative workers from Sharkia Health Directorate were selected using a systematic random technique as for the private sector. Health Directorate was selected as it has a large number of employees and so can cover the required sample. Also for the ease of access and dealing by the researchers as being physicians than other public sectors which may be more complicated.

\section{Sample size:}

Calculations of the sample has been done using Epi Info program at confidence interval $95 \%$, power of test $80 \%$ and the ratio between the two groups is $1 / 1$, provided that, the percent of nonexposed with outcome (psychological distress) is $18 \%$ and the percent of exposed with outcome is $43 \%$ according to Sidorchuk et al., (2017). So, the sample was calculated to be 130 subjects with 65 employees in each group. The sample selection within each group frame followed a systematic random sampling technique till completing the desired number (65). Subjects were eligible to be included if they were aged 20-65 years and currently working in a paid employment job. Employees of non-eligible ages or with unknown employment status were excluded.

\section{Study methods:}

- An interviewed administered 
semi-structured questionnaire was used:

\section{1- First part: Socio-demographic and} occupational characteristics: age, gender, occupation, marital status, lifestyle factors, work duration, work hours per week, income, employment status during the year preceding the study.

2- Second part: Employment precariousness was measured by The Employment Precariousness Scale (EPRES) which is a multidimensional validated questionnaire specifically devised for epidemiological studies among waged and salaried workers. It is composed of 26 items grouped into six subscales: "Temporariness" or instability (e.g. contract duration), "Disempowerment" (e.g., wages, working hours), "Vulnerability" (e.g., unfair, violent), Low wages" (monthly wage/salary, capacity to cover regular or unexpected expenses), "Rights" (entitlement to workplace rights such as sick leave, weekly rest, vacations), and "Capacity to exercise rights" (e.g. maternity/paternity leave, vacations). Subscale scores were computed as simple averages, transformed into a $0-4$ scale, and averaged into a summary score ranging from 0 to 4 (Vives et al., 2010). The total EPRES scale is the arthematic mean of the six subscale score, $<1$ (No-low precariousness), 1-1.99 (moderate), $\geq 2$ (high-very high) with low scores indicating low precariousness and high scores implying high precariousness.

3- Third part: Job insecurity was assessed with the question (To what extent you are worried that you are laid off or you don't renew the contract) as adapted from previous studies (Maurier and Northcott, 2000; Canivet et al., 2016).

4- Fourth part: Minor psychiatric morbidity was estimated using the 12-item general health questionnaire) (GHQ 12) (Goldberg, 1972). The GHQ is a screening tool which was used to identify the severity of psychological distress experienced by an individual within the past few weeks. Each item on the scale has four answers from "better than usual" to "much less than usual." The GHQ-12 was found to contain three underlying factors. These factors were identified as: psychological distress 
(5 items), social and emotional dysfunction (5 items), and cognitive disorder (2 items). For the purpose of this study, the GHQ scoring method (0-0-1-1) was chosen over the simple Likert scale of 0-1-2-3, as this particular method is believed to eliminate any biases which might result from the respondents who tend to choose responses 1 and 4 or 2 and 3, respectively (Goldberg and Williams, 1988). The scores were summed up by adding all the items on the scale ranging from 0 to 12 . In this study, the cut-off point 7 was used to determine the respondents' level of psychological well-being where equal to or more than 7 indicates a poor mental state or severe psychiatric distress according to a study by Sidorchuk et al., (2017).

\section{Pilot study:}

The questionnaire was translated into Arabic by a bilingual co-investigator and back-translated by another bilingual expert to ensure validity. The necessary corrections and rewording after considering any minor differences have been done to ensure the clarity of all questions and ease of understanding. The questionnaire has been tested on 10 workers. The reliability coefficient test (Cronbach's alpha) was $>0.72$ for all questions.

\section{Consent}

An informed consent was obtained from each subject after a simple and clear clarification of the aim of the study and research objectives. Participation was voluntary and confidential and the collected data was for the sole purpose of the study.

\section{Ethical approval}

The necessary official permissions were obtained from the Zagazig University' Institutional Review Board (ZU- IRB \#4214) and managers of firms before data collection.

\section{Data management}

Data were entered and statistically analyzed using the SPSS program version 19.0 (SPSS, Chicago, IL, USA). Normality tests (Shapiro-Wilk test) were performed and revealed the normal distribution of the data. Quantitative data were represented as a mean and standard deviation and qualitative data were represented as frequencies and percentages. The independent student's t-test was used to determine the significance of differences between 
two continuous variables, and the chisquared test was used to assess for differences in the categorical variables. The binary logistic regression model was performed to find the factors predicting psychiatric distress. The test results were considered significant when $\mathrm{p}$-value $<0.05$.

\section{Results}

A total of 130 employees of both private and public sectors were participated in this study. In private sector, employees were of lower ages, mostly male, unmarried with unsatisfied income compared to public sector. A majority $(92.3 \%)$ of the public sector workers were working for more than 2 years compared to $(43.1 \%)$ in the private sector. Forty-six percent of private workers work $>40 \mathrm{hr} /$ week compared to $(1.5 \%)$ in the public sector and minority of them have another or second job $(26.2 \%$ and $7.7 \%$ respectively). All differences were statistically significant $(\mathrm{p}<0.001)$.

\section{Table 1: Means and standard deviations of the Employment Precariousness Scale (EPRES) among the studied participants.}

\begin{tabular}{|l|c|c|c|c||}
\hline \multicolumn{1}{|c|}{ Mean Employment } & Private sector & Public sector & t & p \\
Precariousness Scales & (No=65) & $\mathbf{6 5})$ & \\
\hline Temporariness (2 items) & $3.7 \pm 0.9$ & $0.9 \pm 0.2$ & 24.5 & $\mathbf{0 . 0 0 0 * *}$ \\
\hline Disempowerment (3 items) & $3.0 \pm \cdot, \wedge$ & $2.6 \pm 0.6$ & 3.2 & $\mathbf{0 . 0 0 0 * *}$ \\
\hline Vulnerability (6 items) & $2.7 \pm 0.6$ & $0.7 \pm 0.2$ & 25.5 & $\mathbf{0 . 0 0 0 * *}$ \\
\hline Wages (3 items) & $2.4 \pm 0.7$ & $1.7 \pm 0.4$ & 7.0 & $\mathbf{0 . 0 0 0 * *}$ \\
\hline Rights (7 items) & $3.7 \pm 1.0$ & $0.1 \pm 0.01$ & 29.0 & $\mathbf{0 . 0 0 0 * *}$ \\
\hline Exercise rights (5 items) & $2.5 \pm 0.5$ & $0.1 \pm 0.01$ & 38.7 & $\mathbf{0 . 0 0 0 * *}$ \\
\hline Total Mean EPRES Score & $\mathbf{3 . 0} \pm \mathbf{0 . 1}$ & $\mathbf{1 . 0} \pm \mathbf{0 . 3}$ & 51.0 & $\mathbf{0 . 0 0 0 * *}$ \\
\hline
\end{tabular}

Independent sample $t$ test was used for testing the difference between the two group means $* *$ : Highly statistically significant 
Table 1 showed statistically significantly higher mean scores of all EPRES subscale among private than public sector $(p<0.001)$. A higher mean score of temporariness, rights, disempowerment, and vulnerability was reported for the private sector $(3.7 \pm 0.9,3.7 \pm 1.0,3.0 \pm 0.8$, and $2.7 \pm 0.6$ respectively), and disempowerment and low wages $(2.6 \pm 0.6$, and $1.7 \pm 0.4$ respectively) for the public sector.

Table 2: Prevalence of work precariousness, job insecurity and minor psychiatric morbidity among the studied participants.

\begin{tabular}{|c|c|c|c|c|c|c|}
\hline \multirow[t]{2}{*}{ Variables } & \multicolumn{2}{|c|}{$\begin{array}{c}\text { Private sector (No } \\
=65)\end{array}$} & \multicolumn{2}{|c|}{$\begin{array}{l}\text { Public sector } \\
\qquad(\mathrm{No}=65)\end{array}$} & \multirow[t]{2}{*}{$\chi^{2}$} & \multirow[t]{2}{*}{$\mathbf{p}$} \\
\hline & No & $\%$ & No & $\%$ & & \\
\hline \multirow{4}{*}{$\begin{array}{l}\text { Level of precariousness: } \\
\text { None/low } \\
\text { Moderate } \\
\text { High/very high }\end{array}$} & & & & & \multirow{4}{*}{97.7} & \multirow{4}{*}{$0.000 * *$} \\
\hline & 3 & 4.6 & 52 & 80.0 & & \\
\hline & 5 & 7.7 & 13 & 20.0 & & \\
\hline & 57 & 87.7 & 0 & 0.0 & & \\
\hline \multirow{3}{*}{$\begin{array}{l}\text { Job insecurity: } \\
\text { Yes } \\
\text { NO }\end{array}$} & & & & & \multirow{3}{*}{31.9} & \multirow{3}{*}{$0.000 * *$} \\
\hline & 45 & 69.2 & 13 & 20.0 & & \\
\hline & 20 & 30.8 & 52 & 80.0 & & \\
\hline \multirow{3}{*}{$\begin{array}{l}\text { GHQ12\# } \\
\text { Good mental health } \\
\text { Poor mental health }\end{array}$} & & & & & \multirow{3}{*}{13.4} & \multirow{3}{*}{$0.000 * *$} \\
\hline & 45 & 69.2 & 58 & 89.2 & & \\
\hline & 20 & 30.8 & 7 & 10.8 & & \\
\hline
\end{tabular}

**: Highly statistically significant \#General Health Questionnaire (GHQ12)

Table 2 showed a statistically significant high/very high level of precariousness and job insecurity, $(87.7 \%$, and $69.2 \%$ respectively), $(\mathrm{p}<0.001)$ compared to public sector in which $80.0 \%$ of them showed none or low level of precariousness and $20 \%$ reported job insecurity. As regard minor psychiatric morbidity according to (GHQ12), only $10.8 \%$ of public sector showed poor mental health compared to $30.8 \%$ for the private sector with a highly statistically significant difference $(\mathrm{p}<0.001)$. 
Table 3: The relationship between socio-demographic and occupational characteristics, work precariousness, and perceived job insecurity with the worker's mental health.

\begin{tabular}{|c|c|c|c|c|c|c|}
\hline \multirow{2}{*}{$\begin{array}{l}\text { Socio-demographic and } \\
\text { occupational characteristics }\end{array}$} & \multicolumn{4}{|c|}{ Mental health } & \multirow{2}{*}{$\begin{array}{l}\text { Test of } \\
\text { sig. }\end{array}$} & \multirow[b]{2}{*}{$\mathbf{p}$} \\
\hline & \multicolumn{2}{|c|}{$\begin{array}{c}\text { Good } \\
(\mathrm{No}=98)\end{array}$} & \multicolumn{2}{|c|}{$\begin{array}{c}\text { Poor } \\
(\mathrm{No}=32)\end{array}$} & & \\
\hline $\begin{array}{l}\text { Age (years): } \\
\text { Mean } \pm \mathrm{SD}\end{array}$ & \multicolumn{2}{|c|}{$25.7 \pm 6.4$} & \multicolumn{2}{|c|}{$27.5 \pm 8.6$} & $\begin{array}{c}\mathbf{t} \\
1.3\end{array}$ & 0.2 \\
\hline \multirow{2}{*}{$\begin{array}{l}\text { Gender: } \\
\text { Male } \\
\text { Female }\end{array}$} & No & $\%$ & No & $\%$ & $\chi^{2}$ & \multirow[b]{2}{*}{0.6} \\
\hline & $\begin{array}{l}53 \\
45\end{array}$ & $\begin{array}{l}54.1 \\
45.9\end{array}$ & $\begin{array}{l}16 \\
16\end{array}$ & $\begin{array}{l}50.0 \\
50.0\end{array}$ & 0.2 & \\
\hline $\begin{array}{l}\text { Marital status: } \\
\text { Married } \\
\text { Unmarried }\end{array}$ & $\begin{array}{l}61 \\
37\end{array}$ & $\begin{array}{l}62.2 \\
37.8\end{array}$ & $\begin{array}{l}14 \\
18\end{array}$ & $\begin{array}{l}43.7 \\
56.3\end{array}$ & 3.4 & 0.07 \\
\hline $\begin{array}{l}\text { Residence: } \\
\text { Rural } \\
\text { Urban }\end{array}$ & $\begin{array}{l}49 \\
41\end{array}$ & $\begin{array}{l}50.0 \\
50.0\end{array}$ & $\begin{array}{l}10 \\
22\end{array}$ & $\begin{array}{l}31.3 \\
68.7\end{array}$ & 3.4 & 0.06 \\
\hline $\begin{array}{l}\text { Income: } \\
\text { Not satisfactory } \\
\text { Satisfactory }\end{array}$ & $\begin{array}{l}53 \\
45\end{array}$ & $\begin{array}{l}54.1 \\
45.9\end{array}$ & $\begin{array}{c}29 \\
3\end{array}$ & $\begin{array}{c}90.6 \\
9.4\end{array}$ & 13.8 & $0.000 * *$ \\
\hline $\begin{array}{l}\text { Current Job duration: } \\
\leq 2 \text { years } \\
>2 \text { years }\end{array}$ & $\begin{array}{l}28 \\
70\end{array}$ & $\begin{array}{l}28.6 \\
71.4\end{array}$ & $\begin{array}{l}14 \\
18\end{array}$ & $\begin{array}{l}43.7 \\
56.3\end{array}$ & 2.5 & 0.1 \\
\hline $\begin{array}{l}\text { Work hours/week: } \\
\leq 40 \text { hours } \\
>40 \text { hours }\end{array}$ & $\begin{array}{l}78 \\
20\end{array}$ & $\begin{array}{l}79.6 \\
20.4\end{array}$ & $\begin{array}{l}21 \\
11\end{array}$ & $\begin{array}{l}65.6 \\
34.4\end{array}$ & 2.6 & 0.1 \\
\hline $\begin{array}{l}\text { Another/second job: } \\
\text { Yes } \\
\text { NO }\end{array}$ & $\begin{array}{c}3 \\
95\end{array}$ & $\begin{array}{c}3.1 \\
96.9\end{array}$ & $\begin{array}{l}19 \\
13\end{array}$ & $\begin{array}{l}59.4 \\
40.6\end{array}$ & 54.4 & $0.000 * *$ \\
\hline $\begin{array}{l}\text { Perceived work precariousness: } \\
\text { Yes } \\
\text { NO }\end{array}$ & $\begin{array}{l}44 \\
54\end{array}$ & $\begin{array}{l}44.9 \\
55.1\end{array}$ & $\begin{array}{c}31 \\
1\end{array}$ & $\begin{array}{c}96.9 \\
3.1\end{array}$ & 26.7 & $0.000 * *$ \\
\hline $\begin{array}{l}\text { Perceived job insecurity: } \\
\text { Yes } \\
\text { NO }\end{array}$ & $\begin{array}{l}26 \\
72\end{array}$ & $\begin{array}{l}26.5 \\
73.5\end{array}$ & $\begin{array}{c}32 \\
0\end{array}$ & $\begin{array}{c}100 \\
0.0\end{array}$ & Fisher & $0.000 * *$ \\
\hline
\end{tabular}

**: Highly statistically significant 
Table 3 showed that workers with poor mental health were highly statistically significantly $(\mathrm{p}<0.001)$ unsatisfied with their income, had another/second job, had work precariousness and all of them perceived job insecurity, $(90.6 \%, 59.4 \%$, $96.9 \%$, and $100 \%$ respectively) compared to workers with good mental health (54.1\%, 3.1\%, 44.9\%, and $26.5 \%$ respectively).

Table 4: Regression analysis for prediction of perceived psychiatric distress among the studied workers.

\begin{tabular}{|c|c|c|c|c|c|c|}
\hline \multirow{2}{*}{ Variables } & \multirow{2}{*}{ B } & \multirow{2}{*}{ SE } & \multirow{2}{*}{ p value } & \multirow{2}{*}{$\begin{array}{l}\text { Expected } \\
\text { (B) }\end{array}$} & \multicolumn{2}{|c|}{$\begin{array}{c}95 \% \text { CI } \\
\text { For expected B }\end{array}$} \\
\hline & & & & & $\begin{array}{l}\text { Lower } \\
\text { bound }\end{array}$ & $\begin{array}{l}\text { Upper } \\
\text { bound }\end{array}$ \\
\hline Income (Not satisfactory) & 3.2 & 0.34 & $0.01 *$ & 1.8 & 1.12 & 2.43 \\
\hline Presence of another/second job & 2.0 & 0.16 & $0.02 *$ & 1.4 & 1.08 & 1.79 \\
\hline Perceived work precariousness & 16.8 & 2.3 & $0.009 *$ & 4.1 & 1.78 & 21.42 \\
\hline
\end{tabular}

*: Statistically significant

Table 4 showed that background variables as unsatisfied income and the work determinants as having another or second job and perceived work precariousness are significant predictors for psychiatric distress $(p<0.05)$.

\section{Discussion}

To our knowledge this study is one of the first few studies conducted in Egypt to study precarious work, job insecurity, and clarify their roles on the worker's mental health and psychological well-being. Our findings are in line with previous study conducted by Do Monte (2017) which reported stronger participation of younger workers in private sector jobs compared to older workers in the public sector and attributed their findings to the fact that young workers are more likely to change their jobs compared to older ones, in order to gain professional experience and to find a better job. Furthermore, this result could be explained by the fact that as most of the workers in the developing countries delay in their governmental recruitment and for earning money, they usually start 
their working life early in the private sector even in irrelevant specialty for a period of time till their governmental recruitment is obtained. Moreover, the private sector tends to employ younger workers who are viewed as more productive and less costly compared to older one (Do Monte, 2017).

Wage, salary or pay is considered a significant reward to motivate the workers and their behavior towards the goals of the employer (Oshagbemi, 2000). However, the wages rates in Egyptian public sector are low and have not satisfied public employees with a noticeable public-private earnings gap. The current results confirm previous research (Borges, 2013) showing that public sectors are less satisfied with their income than private sector workers. In contrast, other study from Philippines reported that public sector workers received higher hourly wages than private sector workers (Molato, 2015). However, private sector wages start to be low and cut down due to recent political and macroeconomic instability. These differences in publicprivate wages might be related to regional economic divergence, growth, and challenges.

As regards to the occupational characteristics, this study reported that private sectors workers had longer working hours and lower work duration than the public ones. These results are in agreement with Dur and Zoutenbier (2013) who reported that government employees work fewer hours, relatively lazy, risk-averse and are less specialized in skills compared with their private sector counterparts. This difference in both sectors could be explained by the fact that accounting absences in the private sector are done in a more rigorous way than in the public sector, where the allowance of absences is most common without problems. Moreover, public sectors workers do not tend to do unpaid overtime work comparable to those in the private sector (Do Monte, 2017).

The current study showed higher significant total mean scores of all EPRES among private than the public sector $(p<0.001) \quad($ Table 1). This finding is consistent with previously documented facts that governmental work in some sort of governmental agencies is more stable, less precarious, secured, fixed, have uncommon turnover, lower dismissal rate, so consequently have higher tenure and more attractive to security-seeking 
employees than in the private sector (Gonzaga et al., 2003). On contrary, the private work is unstable or fairly stable, more precarious, liable for frequent changes, turnover, irregular wages and termination at any time.

In our country, despite private work tends to be well paid with more privileges, better working environment than public sector; but this study showed that private sector has higher items subscales of the EPRES than public sector especially for temporariness, rights, disempowerment and vulnerability $(3.7 \pm 0.9,3.7 \pm 1.0,3.0$ \pm 0.8 , and $2.7 \pm 0.6$ respectively) (Table 1). This finding is possibly due to the fact that workers of private sectors are hired under different labor conditions than public sector employees, who are hired under the administrative state with a mass of legal controls. Furthermore, it has been observed that constancy in getting a permanent monthly pay as in public sector is much desired by the personnel as compared to incentive or enticement based salary packages which are adjustable in nature and make private sector workers and their families living without stability (Molato, 2015). Further explanation for this finding is the nature of the private work in which contract renewal is subjected to the conditions of the employer, ownership factor, annual evaluation, rating which may be subjective rather than objective, economic conditions, wages bargaining or negotiating, realized profits, disempower women and downsizing in some instances which all make continues threat to the workers well-being, their families and increase their perception of work precariousness compared to public sector workers. Moreover, the deterioration of economic conditions in Egypt between 2009 and 2014 has driven private sector employment to become increasingly vulnerable and precarious. This is because precarious employment in Egypt is very sensitive to economic changes, it increases in recessions and declines in booms as reported by Assaad and Krafft (2015).

Despite the public sector reported lower items subscales scores of employment precariousness compared to the private sector; however, disempowerment and low wages (2.6 \pm 0.6 , and $1.7 \pm 0.4$ respectively) were the highest reported items (Table 1). Indeed, this finding is consistent with the fact that public sector in Egypt due to deficit in fiscal resources has low salaries and wages which is insufficient 
to meet living expenses and much lower than surrounding countries [Egypt's minimum wage rate is LE 1,200 (around \$68 per month)] (Labor and employment datasheet Egypt, 2018). Thus, there is a real need to modify the minimum wage policy in Egypt and therefore the entire grade scales.

In addition, Rainey and Chun (2005) stated that people who work in the public sector have a lower level of incentive and motivation, uncomfortable working environment, and in some instances, unpaid or not worthy overtime work than those in the private sector. Also, as public employees operate in an environment where wages are compressed, so even highly skilled workers have little chance of ever earning a lot of money (Borjas, 2002). On the other hand, another study reported that employees in the public sector feel more secure about their future and less fearful of being dismissed for excessively working absences as in the private sector. In addition, they have shorter, more flexible working hours without deduction from salary as in private work and so might decrease their perception of work precariousness. Moreover, the degree of employment protection for public sector employees largely exceeding that in the private sector, as health insurance and occupational health insurance could explain these private-public differences (Labriola et al., 2006).

Recently, in Egypt, there is a sharp increase in the prevalence of precarious employment, particularly among youth, and the situation has worsened since 2011 as reported by Assaad and Krafft (2013). The present study showed that private sector workers had higher frequencies of high/very high level of precariousness $(87.7 \%)$, job insecurity $(69.2 \%)$, and poor mental health $(30.8 \%)$ compared to public sector (Table 2). Also, data collected in 2004-2005 on a representative sample of the Spanish workforce showed a high prevalence of employment precariousness, affecting nearly 6.5 million workers, with almost 900,000 of them exposed to high precariousness (Vives et al., 2011). In addition, a study conducted longitudinally with multiple follow-ups in Sweden concluded that $42 \%$ of the participants had a precarious employment (Kim et al., 2012). A higher level of work precariousness in our study than other previous studies could be attributed to the current economic downturn and financial crisis that Egypt 
faces. Furthermore, it is often argued that well- developed welfare states with active labor market policies can buffer the negative effects of a precarious labor market (Kim et al., 2012).

Regarding the issue of mental health and psychiatric distress, a study by Lager and Bremberg (2009) suggested that recent changes in the labor market, increasing the risk of experiencing precariousness, have contributed to the rapidly deteriorating trend in mental health among young people. Moreover, a review conducted in 2014 by Benach et al., found studies supporting a linkage between mental health problems and major organizational restructuring and downsizing, perceived job insecurity, and temporary employment. The current study reported that private sectors workers had higher poor mental health than the public ones. In contrast to our finding, previous report by US BLS (2011) documented that public sector employees have been found to report higher levels of psychological distress than private sector counterparts. Explanation of these findings could be related to the fact that most the public sector workers are older than private sector workers and psychological distress tends to increase as age increases. In addition, healthy worker effect among private sector workers may explain the low level of poor mental health which suggests that continued health-related selection out of the workforce is stronger in private than public workers. On contrary, a systematic review conducted by Dos Santos (2016) commented that the public sector employees are become also vulnerable to poor mental health, mainly when it is subjected to organizational changes similar to private sector concepts.

Concerning factors affecting the studied workers' mental health (Table 3 ), our results showed that workers with poor mental health were highly statistically significantly $(\mathrm{p}<0.001)$ unsatisfied with their income, had another/second job, had work precariousness and all of them perceived job insecurity compared to workers with good mental health. These findings are in agreement with a study conducted by Meltzer et al., (2002) who revealed that lowest income quintile of the population has twice the probability of facing mental health problems compared to average income earners. On the other 
hand, Blanchflower and Oswald (2008) reported that though wages constitute the core element of income for lowearning individuals, there is limited evidence on the causal effect of wages on mental health. Despite multiple jobs holders being common in many countries, previous research has found diversity concerning the association between having a second job and poor mental health (Marucci-Wellman et al., 2016). Reason for this diverse could be attributed to the heterogeneity of the studied workers regarding their demographics background, health and different work characteristics.

Poor mental health is proposed as the most likely health outcome of employment precariousness (Amable et al., 2001; Vives et al., 2010). Our results in the present study revealed that income un-satisfaction, the presence of another or second job, and perceived work precariousness, are the most significant predictors for perceived psychiatric distress among the studied workers (Table 4). Additionally, recent study using prospective data have verified an association running from perceived job insecurity, to subsequent poorer mental health (De Witte et al., 2016). Moreover, in 2015, Glavin found that persistent job insecurity is a stronger predictor of poor mental health.

\section{Conclusion and recommendations:}

The results of the current study raise the attention that private sector workers suffered a higher prevalence of work precariousness, job insecurity, and poor mental health in comparison to public sector workers. The novelty of our study is the investigation of precarious employment and the relevance of job insecurity, and other employment conditions as a predictor of psychiatric distress which necessitate urgent interventions with policy tools aimed at strengthening the perceived insecurity and alleviating mental health distress among precarious workers in order to improve the health promotion of workers, increase firms' productivity, and so wider economic impact.

\section{Conflict of interest}

None declared.

\section{Funding}

None.

\section{Acknowledgment}

The authors dedicate their sincere appreciation to the participating employees for their cooperation; similarly, we express our gratitude to 
the principals of private companies and Sharkia Health Directorate for their help in facilitating data collection.

\section{References}

1. Aita S (2017): The informal employment in the Arab countries Realities and Rights Launching the Regional Report Beirut, Cairo May 8 and 9, 2017. Available at https://www.wiego.org/ sites/default/files/resources/files/InformalEmployment-Arab-Countries-Aita-2017.pdf.

2. Amable M, Benach J and González S (2001): La precariedad laboral y su repercusión sobre la salud: conceptos y resultados preliminaries de un estudio multimétodos. Archivos de Prevencio'n y Riesgos Laborales; 4(4): 169-84.

3. Assaad R and Krafft C (2013): The Evolution of Labor Supply and Unemployment in the Egyptian Economy: 1988-2012. In: Economic Research Forum Working Papers; Working paper No. 806.

4. Assaad R and Krafft C (2015): Why the Unemployment Rate Is a Misleading Indicator of Labor Market Health in Egypt, 14 In: Economic Research Forum Policy Perspective No 32. Available at http://erf.org.eg/publications/ why-the-unemployment-rate-is-a-misleadingindicator-of-labor-market-health-in-egypt/

5. Benach J, Vives A, Amable M, Vanroelen C, Tarafa G, et al. (2014): Precarious employment: understanding an emerging social determinant of health. Annu Rev Public Health; 35:229-53. doi: 10.1146/annurev-publhealth-032013-182500.

6. Blanchflower D and Oswald A (2008): Hypertension and happiness across nations. Journal of Health Economics; 27(2):218-33. [PubMed].

7. Borges R (2013): Are public officials really less satisfied than private sector workers? A comparative study in Brazil. Rev Adm Pública [online]; 47(6): 1477-1496 .Available at: http:// www.scielo.br/scielo.php?script=sci_arttext\&p $\mathrm{id}=$ S0034-76122013000600007.

8. Borjas G (2002): The Wage Structure and the Sorting of Workers into the Public Sector NBER Working Paper No. 9313, JEL No. J3, J4. Available at: http://www.nber.org/papers/ w9313.

9. Canivet $\mathrm{C}$, Bodin T, Emmelin M, Toivanen S, Moghaddassi M, et al. (2016): Precarious employment is a risk factor for poor mental health in young individuals in Sweden: a cohort study with multiple follow-ups. BMC Public Health; 16:687. DOI 10.1186/s12889-0163358-5.

10. De Witte H, Pienaar J and De Cuyper N (2016): Review of 30 Years of Longitudinal Studies on the Association Between Job Insecurity and Health and Well-Being: Is There Causal Evidence? Australian Psychologist; 51:18-31.

11. Do Monte P (2017): Public versus private sector: Do workers' behave differently? Economi A; 18:229-43.

12. Dos Santos M (2016): Government employees and depressive and anxiety disorders: A systematic review. European Psychiatry; S157.

13. Dur R and Zoutenbier R (2013): Intrinsic motivations of public sector employees: Evidence for Germany. SOEP papers on Multidisciplinary Panel Data Research.

14. Egypt $\square$ s government services portal (2017): Available at http://www.egypt.gov.eg/english/ laws/labour/www.mahermiladiskander.com [accessed 20 July 2017].

15. Glavin P (2015): Perceived Job Insecurity and Health: Do Duration and Timing Matter? The Sociological Quarterly; 56:300-28.

16. Goldberg D (1972): The detection of psychiatric illness by questionnaire: A technique for the identification and assessment of non-psychotic psychiatric illness. London, New York: Oxford University Press.

17. Goldberg D and Williams P (1988): User's guide to the General Health Questionnaire. Windsor UK: NFER-Nelson.

18. Gonzaga G, Maloney W and Mizala A (2003): 
Labour turnover and labour legislation in Brazil [with comments] Economía; 4 (1): 165-222. Cross Ref View Record in Scopus Google Scholar

19. International Labour Organization- ILO (2012): 'From precarious work to decent work: outcome document to the workers' symposium on policies and regulations to combat precarious employment', International Labour Organization; Geneva.

20. Kim I, Muntaner C, Vahid Shahidi F, Vives A, Vanroelen C, et al. (2012): Welfare states, flexible employment, and health: a critical review. Health Policy; 104:99-127.

21. Labor and employment datasheet Egypt. Egypt minimum wages, Minimum wage rate (2018): available at https://www.minimum-wage.org/ international/egypt.

22. Labriola M, Lund $T$ and Burr $H$ (2006): Prospective study of physical and psychosocial risk factors for sickness absence. Occup Med (Lond); 56:469-74.

23. Lager A and Bremberg S (2009): Association between labour market trends and trends in young people's mental health in ten European countries 1983- 2005. BMC Public Health; 9:325.

24. Marucci-Wellman H, Lombardi $D$ and Willetts J (2016): Working multiple jobs over a day or a week: short-term effects on sleep duration. Chronobiol Int; 33:1-20. doi: 10.3109/07420528.2016.1167717. [PMC free article] [PubMed] [Cross Ref].

25. Maurier W and Northcott H (2000): Job uncertainty and health status for nurses during restructuring of health care in Alberta. Western Journal of Nursing Research; 22(5), 623-41.

26. Meltzer H, Singleton N, Lee A, Bebbington P, Brugha T, et al. (2002): The social and economic circumstances of adults with mental disorders, Stationery Office.

27. Molato R (2015): Public-Private Wage Differentials and the Quality of Government Workers in the Philippines Max Planck Institute for Tax Law and Public Finance Working Paper; -06. Department of Business and Tax Law Department of Public Economics. http:// www tax.mpg.de.

28. Muntaner C, Chung H, Solar O, Santana V, Castedo A, et al. (2010): A macro-level model of employment relations and health inequalities. International Journal of Health Services; 40 (2), 215-21.

29. Oshagbemi T (2000): Correlates of pay satisfaction in higher education. International Journal of Educational Management; 14(1), 319.

30. Puig-Barrachina V, Vanroelen C, Vives A, Martinez J, Muntaner C, et al. (2014): Measuring employment precariousness in the European Working Conditions Survey: the social distribution in Europe. Work, 49:143-61.

31. Rainey H and Chun Y (2005): Public and private management compared. In: Ferlie, E., Lynn, L., Pollitt, C. (Eds.). The Oxford Handbook of Public Management. Oxford University Press, Oxford, UK; 233-44.

32. Rashad A and Sharaf M (2018): Does precarious employment damage youth mental health, wellbeing, and marriage? Evidence from Egypt using longitudinal data. Working Paper 1200. Economic research form (ERF); Available at https://erf.org.eg/wp-content/ uploads/2018/05/1200_Final.pdf.

33. Ruiz M, Vives A, Martínez-Solanas E, Julià $M$ and Benach J (2017): How does informal employment impact population health? Lessons from the Chilean employment conditions survey. Safety science; 100, part A: 57-65.

34. Sidorchuk A, Engström K, Johnson C, Kayser Leeoza N and Möller J (2017): Employment status and psychological distress in a populationbased cross-sectional study in Sweden: the impact of migration. BMJ Open; 7(4): e014698. doi: 10.1136/bmjopen-2016-014698.

35. United States Bureau of Labor Statistics (US BLS) (2011): Incidence rates of nonfatal occupational injuries and illnesses by case type 
and ownership. Washington DC; Available at: www.bls-gov/news.release/osh/t01.htm.

36. Vives A, Amable M and Ferrer M (2010): Employment Precariousness Scale (EPRES): psychometric properties of a new tool for epidemiological studies among waged and salaried workers," Occupational and Environmental Medicine; 67(8):548-55. doi: 10.1136/oem.2009.048967. Epub 2010 Jun 24.

37. Vives A, Vanroelen C, Amable M, Ferrer M, Moncada S, et al. (2011): Employment Precariousness in Spain: Prevalence, Social Distribution, and Population-Attributable Risk Percent of Poor Mental Health. International Journal of Health Services; 41(4): 625 - 64. 
